\title{
KARAKTERISTIK NILAI GIZI DAN MUTU SENSORI SOSIS IKAN GULAMAH (Nibea albiflora) DENGAN PENAMBAHAN DAGING AYAM
}

\section{CHARACTERISTICS OF NUTRITIONAL VALUES AND QUALITY OF SUGAR FISH SOCIALITY (Nibea albiflora) WITH ADDITION OF CHICKEN MEAT}

\author{
Nurhikma $^{{ }^{*}}$, Novi Luthfiyana ${ }^{1}$, Diana Maulianawati ${ }^{2}$, Ade Fitriani $^{2}$ \\ ${ }^{1}$ Departemen Teknologi Hasil Perikanan, Fakultas Perikanan dan Ilmu Kelautan Universitas Borneo Tarakan \\ ${ }^{2}$ Departemen Aquakultur, Fakultas Perikanan dan Ilmu Kelautan Universitas Borneo Tarakan \\ *Nurhikma.4991@gmail.com
}

Diterima (receive) : 18 September 2019; Disetujui (accepted) : 30 Oktober 2019

\begin{abstract}
ABSTRAK
Penelitian ini bertujuan untuk meningkatkan kualitas fisik produk sosis ikan dengan penambahan daging ayam broiler sehingga memberikan tekstur yang lebih baik pada sosis ikan dan mampu meningkatkan penerimaan sosis ikan pada konsumen. Pada penelitian ini dilakukan 2 perlakuan yakni sosis ikan 100\% dan sosis ikan dengan penambahan daging ayam $30 \%$ kemudian dilakukan uji mutu sensori menggunakan uji kesukaan skala 1-7 dan uji proksimat. Sosis ikan gulamah $100 \%$ menghasilkan kenampakan (5,17\%), aroma dan tekstur $(5,00 \%)$, dan rasa $(5,40 \%)$ dengan protein sebesar $(6,67 \%)$ sedangkan sosis ikan dengan penambahan daging ayam (30\%) memberikan kenampakan $(4,90 \%)$, aroma $(5,33 \%)$ tekstur $(4,83)$, dan rasa $(5,80 \%)$ dengan protein sebesar $(7,45 \%)$. Diharapkan sosis ikan ini dapat dikomersialkan guna meningkatkan 'nilai tambah ikan gulamah, dengan baiya produksi relative murah dibandingkan dengan sosis daging ataupun sosis ayam. Hasil uji organoleptik internal menunjukkan bahwa sosis ikan cukup memuaskan responden, rasa dapat diterima dan cukup disukai.
\end{abstract}

Kata Kunci: nilai gizi, uji mutu sensori, sosis ikan

\begin{abstract}
This study aimed to improve the physical quality of fish sausage products by adding broiler chicken meat so that it gives a better texture to fish sausages, and it can increase the reception of fish sausages to consumers. In this study, two treatments were carried out, namely $100 \%$ fish sausage and fish sausage with $30 \%$ chicken meat addition then sensory quality testing using 1-7 scale favorite test and proximate test. $100 \%$ Gulamah fish sausage produces appearance (5.17\%), aroma and texture (5.00\%), and taste (5.40\%) with protein (6.67\%) while fish sausage with the addition of chicken meat (30\%) gives an appearance (4.90\%), aroma (5.33\%) texture (4.83), and taste (5.80\%) with protein (7.45\%). This fish sausage is expected to be commercialized to increase the added value of gulamah fish, with the production cost is relatively cheap compared to meat sausage or chicken sausage. The results of the internal organoleptic test showed that fish sausage was satisfactory enough, the taste was acceptable and quite acceptable.
\end{abstract}

Keywords: nutritional value, sensory quality testing, fish sausage 


\section{PENDAHULUAN}

Menganekaragamkan produk olahan hasil perikanan perlu dikembangkan di masyarakat sehingga dapat dijadikan sebagai bahan alternatif bagi masyarakat dalam mengkonsumsi ikan. Mengkonsumsi produk olahan ikan atau produk yang mengandung ikan, merupakan upaya dalam meningkatkan nilai gizi masyarakat melalui protein ikan. Salah satu bentuk dari aneka produk olahan hasil perikanan yakni sosis ikan.

Hasil tangkapan ikan gulamah di Kota Tarakan cukup melimpah, namun pemanfaatannya masih sangat terbatas. Ikan gulamah (Nibea albiflora) merupakan salah satu jenis ikan demersal yang kurang diminati masyarakat Kota Tarakan karena memiliki rasa yang hambar dari daging. Padahal Ikan Gulamah memiliki daging yang putih, lembut, tebal dan mempunyai nilai ekonomi dan protein yang cukup tinggi sebesar (16,48\%), kandungan lemak (1,47\%), kadar air (79,35\%) menurut Leha dan Moniharapon (2013). Tan et al., (1987) menyatakan bahwa jenis-jenis ikan demersal yang memiliki daging putih sangat baik digunakan untuk membuat "fish jelly products" seperti sosis ikan.

Sosis ikan adalah produk daging lumat atau daging giling yang bersifat kenyal dan berbentuk silinder yang dicampuri bumbu dan dibungkus dengan pembungkus khusus (casing). Pembuatan sosis ikan perlu adanya bahan pengisi selain tepung tapioka, tepung maizena, juga ada penambahan daging ayam sebagai bahan pengikat sehingga membentuk tekstur yang padat, menurunkan penyusutan pada waktu pemasakan, memperbaiki cita rasa dan sifat irisan. Afrisanti (2010) mengatakan bahwa bahan pengisi berfungsi untuk meningkatkan daya memerangkap air, akan tetapi memiliki pengaruh yang kecil terhadap emulsi, menambah bobot produk dengan mensubstitusi sebagian daging sehingga biaya dapat ditekan, berperan dalam pembentukan struktur dan tekstur pada sosis. Muchbianto (2009) menambahkan kisaran nilai daya ikat air ayam broiler segar yaitu sebesar 25-38\%. Daya ikat air ini pula berhubungan dengan protein karena molekul-molekul air bebas berjumlah sekitar $10 \%$ terikat diantara molekul protein akan menurun bila protein daging mengalami denaturasi (Soeparno, 2005).

Penelitian ini menggunakan penambahan daging ayam broiler yang diharapkan mampu meningkatkan kualitas fisik produk sosis ikan, seperti memberikan tekstur yang lebih baik pada sosis ikandan mampu meningkatkan penerimaan sosis ikan pada konsumen. 


\section{BAHAN DAN METODE}

\section{Bahan dan Alat}

Bahan yang digunakan adalah daging ikan gulamah (Nibea albiflora), daging ayam broiler bagian dada, garam, gula, merica halus, bawang merah, bawang putih, air es, tepung tapioka, tepung maizena, dan minyak goreng. Alat yang digunakan pisau, panci besar, food processor, sendok makan, casing sosis, sendok the, timbangan, blender, kompor gas, talenan, benang jahit, saringan ayakan, gunting, sarung tangan, timbangan analitik.

\section{Prosedur Penelitian}

\section{Proses pembuatan sosis ikan gulamah}

\section{(Nibea albiflora)}

Penelitian dilakukan dengan cara pengambilan daging ikan gulamah (Nibea albiflora) sebanyak 200 g, kemudian dilakukan proses pencucian dengan air es sebanyak 3 kali 15 menit. Daging ikan gulamah digiling dengan penggiling daging (food processor). Pada proses penggilingan ditambahkan air es 5\% dari berat daging ikan gulamah yang bertujuan untuk mempertahankan suhu daging ikan agar tetap rendah selama penggilingan. Daging ikan gulamah yang telah digiling dicampur dengan bumbu (bawang merah 0,5\%, bawang putih 0,5\%, lada 0,10\%, gula pasir $2 \%$, garam $2 \%$, tepung maizena $5 \%$, tepung tapioka 10\%, daging ayam broiler 30\% (perlakuan 1) dan daging ikan gulamah 100\% (perlakuan 2). Proses pencampuran bumbu dilakukan selama 3 menit dengan kecepatan rendah sambil memasukkan minyak sawit sebanyak $10 \%$. Setelah itu, adonan dimasukkan ke dalam casing (selongsong) dengan panjang $10 \mathrm{~cm}$ dan berat $15 \mathrm{~g}$ pada tiap batang sosis, kemudian sosis ikan dimasak dengan cara dikukus pada suhu $85^{\circ} \mathrm{C}$ selama 30 menit. Setelah matang, sosis didinginkan pada suhu kamar selama \pm 3 jam.

\section{Metode Analisis}

Metode analisis parameter terhadap sosis ikan gulamah meliputi mutu sensori menggunakan uji kesukaan skala 1-7 dengan panelis 30 orang (Carpenter et al., 2000). Nilai gizi yang diamati pada sosis ikan gulamah meliputi kadar air metode thermogravimetri (AOAC, 2005), kadar protein metode mikro kjeldahl (AOAC, 2005), kadar abu metode langsung (Sudarmadji, 1997), kadar lemak metode soxhlet (AOAC, 2005).

\section{HASIL DAN PEMBAHASAN}

\section{Mutu Sensori Sosis Ikan Gulamah (Nibea albiflora)}

Uji sensori pada penelitian ini menggunakan uji penerimaan yang bertujuan untuk mengevaluasi daya terima panelis terhadap produk yang dihasilkan. Skala 
hedonik yang dihasilkan berkisar 1-7, dimana:

(1) sangat tidak suka; (2) tidak suka; (3) agak tidak suka; (4) normal; (5) agak suka; (6) suka; (7) sangat suka. Uji sensori yang dilakukan menggunakan panelis sebanyak 30 orang berusiausia 20-35 tahun. Sampel yang digunakan adalah krim yang telah diberi perlakuan dan menggunakan sediaan krim komersial sebagai pembanding. Adapun uji sensori skala hedonik sosis gulamah (Nibea albiflora) adalah sebagaimana tersaji pada Tabel 1.

Tabel 1. Uji Sensori Skala Hedonik Sosis Ikan Gulamah (Nibea albiflora)

\begin{tabular}{lcccc}
\hline \multirow{2}{*}{ Parameter } & \multicolumn{4}{c}{ Formula Sosis } \\
\cline { 2 - 5 } & $\begin{array}{c}\mathrm{A} \\
\text { (Ikan70\%+ayam30\%) }\end{array}$ & $\begin{array}{c}\text { B } \\
\text { (Ikan 100\%) }\end{array}$ & $\begin{array}{c}\text { C } \\
\text { (Komersial 1) }\end{array}$ & $\begin{array}{c}\text { D } \\
\text { (Komersial 1) }\end{array}$ \\
\hline Kenampakan & $4,90 \pm 0,97$ & $5,17 \pm 0,98$ & $5,30 \pm 1,17$ & $5,00 \pm 1,07$ \\
\hline Aroma & $5,33 \pm 1,00$ & $5,00 \pm 0,87$ & $3,87 \pm 1,07$ & $4,73 \pm 1,22$ \\
\hline Tekstur & $4,83 \pm 0,99$ & $5,00 \pm 0,80$ & $4,70 \pm 1,01$ & $5,30 \pm 0,90$ \\
\hline Rasa & $5,80 \pm 0,76$ & $5,40 \pm 1,01$ & $4,03 \pm 1,24$ & $4,90 \pm 1,45$ \\
\hline
\end{tabular}

\section{Kenampakan}

Kenampakan memiliki peranan penting dalam membangkitkan ketertarikan dan penerimaan konsumen terhadap suatu produk. Apabila kenampakanya baik atau disukai, maka konsumen akan tertarik untuk melihat karakteristik lainnya. Putri (2009), melaporkan bahwa warna makanan memiliki peranan utama dalam penampilan makanan, meskipun makanan tersebut lezat, tetapi bila penampilan tidak menarik waktu disajikan akan mengakibatkan selera orang yang akan memakannya menjadi hilang.

Nilai kesukaan panelis terhadap kenampakan sosis berkisar antara 4,90 - 5,30 yang berarti bahwa panelis memberikan penliaian antara normal sampai agak suka. Karakteristik keempat sosis adalah bulat lonjong, homogen, mengkilat, sedikit berpori dan terdapat perbedaan warna pada sosis $A$ dan B yaitu putih dan sosis C dan D agak merah. Hasil uji Kruskal-Walis menunjukkan bahwa penambahan ikan gulamah tidak memberikan pengaruh terhadap tingkat kesukaan kenampakan sosis.

\section{Aroma}

Aroma merupakan parameter pengujian yang penting dalam industri pangan karena dapat dengan cepat menentukan penerimaan konsumen terhadap produk. Nilai kesukaan panelis terhadap aroma sosis berkisar antara 3,87 - 5,33 yang berarti bahwa panelis memberikan penliaian antara agak tidak suka sampai agak suka. Hasil uji Kruskal-Walis menunjukkan bahwa penambahan ikan gulamah tidak memberikan 
pengaruh terhadap tingkat kesukaan aroma sosis.

Tidak adanya pengaruh terhadap parameter aroma pada sosis diduga karena keempat sosis mengandung bumbu dasar yang sama seperti penambahan bawang, sehingga konsumen cenderung memberikan penilaian yang tidak berbeda nyata. Hui et al. (2001), melaporkan bahwa penggunaan bumbu pada produk pangan bertujuan untuk memberikan aroma pada produk pangan tersebut. Komponen bumbu seperti bawang mengandung zat aliin yang menyumbangkan rasa dan aroma pada sosis. Harmain (2011), menyatakan bahwa penggunaan bumbu yang sama akan memberikan nilai sensori yang tidak jauh berbeda.

\section{Tekstur}

Pengamatan terhadap tekstur sosis dilakukan dengan cara penentuan tingkat kesukaan tekstur secara sensorik berdasarkan sensasi tekanan didalam mulut ketika digigit, dikunyah, ditelan dan dengan perabaan menggunakan jari Parameter tekstur sosis dilakukan dengan uji sensori skala hedonik. Nilai kesukaan panelis terhadap tekstur sosis berkisar antara 4,70 - 5,30 yang berarti bahwa panelis memberikan penliaian antara normal sampai agak suka. Hasil uji KruskalWalis menunjukkan bahwa penambahan ikan gulamah tidak memberikan pengaruh terhadap tingkat kesukaan aroma sosis.

\section{Kemampuan protein untuk menyerap} dan menahan air mempunyai peranan penting dalam pembentukan tekstur suatu produk pangan Menurut Lawrie (1995), kesan terhadap tekstur melibatkan tiga aspek, yaitu mudah tidaknya gigi berpenetrasi awal ke dalam daging, mudah tidaknya daging tersebut dapat dipecah menjadi bagianbagian yang kecil dan jumlah residu yang tinggal setelah dikunyah.

\section{Rasa}

Parameter Rasa dalam makanan merupakan faktor paling utama terhadap penerimaan konsumen. Formulasi seperti daging ikan dan bumbu-bumbu akan memberikan citarasa sosis. Komponen daging dan bumbu menghasilkan kesan mutu rasa yang seragam atau tidak berbeda. Daging ikan berperan menciptkan rasa gurih karena mengandung protein dan bumbu menciptakan rasa khas seperti pedas, asin, manis dan gurih. Ellmore (1994), melaporkan bahwa di dalam bumbu terdapat senyawa yang bertanggung jawab pada rasa tertentu seperti senyawa piperine (pada lada), dan chavicine (pada cabe), pada bawang putih dan bombay mengandung senyawa diallysulfide 
Nilai kesukaan panelis terhadap rasa sosis berkisar antara 4,03 - 5,80 yang berarti bahwa panelis memberikan penliaian antara normal sampai agak suka. Hasil uji KruskalWalis menunjukkan bahwa penambahan ikan gulamah tidak memberikan pengaruh terhadap tingkat kesukaan aroma sosis.

\section{Analisis Proksimat Sosis Ikan Gulamah (Nibea albiflora)}

Analisis proksimat sosis ikan gulamah (Nibea albiflora) dan daging ikan gulamah yang dapat dilihat pada tabel 2 analisis proksimat menunjukkan bahwa sosis ikan gulamah dengan penambahan daging ayam (A) yaitu kadar air $(72,11 \%)$, kadar abu $(1,86 \%)$, protein $(7,45 \%)$, dan lemak kasar $(13,26 \%)$. Sedangkan nilai proksimat untuk sosis ikan gulamah tanpa penambahan daging ayam (B) yaitu terdiri dari kadar air $(63,92 \%)$, kadar abu $(1,66 \%)$, protein $(6,67 \%)$, dan lemak kasar (13,20 \%). Kandungan proksimat ikan gulamah (Nibea albiflora) segar (C) adalah kadar abu 1,81\%, protein $18,57 \%$, dan lemak kasar 1,86 \% (Xu et al. 2010).

Table 2. Komposisi proksimat sosis dan daging ikan gulamah (Nibea albiflora)

\begin{tabular}{ccccc}
\hline Sampel & Kadar Air (\%) & Kadar Abu (\%) & Protein (\%) & Lemak (\%) \\
\hline A & 72,11 & 1,86 & 7,45 & 13,26 \\
B & 63,92 & 1,66 & 6,67 & 13,20 \\
C $^{*}$ & - & 1,81 & 18,57 & 1,86 \\
\hline
\end{tabular}

Keterangan:

*Sumber : Xu et al, 2010

(-) tidak ada data pengukuran

Kadar air pada produk sosis ikan gulamah menunjukkan hasil yang sama dengan produk sosis berbahan dasar ikan lainnya. Hasil uji proksimat beberapa sosis ikan komersial menunjukkan kadar air sekitar 67,33 - 73,36\% (Huda et al., 2012). Namun hasil ini masih lebih tinggi dibandingkan dengan sosis ikan lele dumbo (64,76\%), ikan kembung (44,48\%), dan ikan kurisi (63,33\%) (Anggaraini et al. 2016; Nalendrya et al., 2016; Widodo, 2008). Penambahan air pada produk sosis bertujuan untuk memudahkan proses pencampuran bahan utama dalam proses pembuatan sosis, namun penambahan air secara signifikan juga dapat mempengaruhi kerekatan dari sosis dan mempengaruhi warna sosis sehingga cenderung berwarna putih (Park, 2000). Nilai kadar air pada produk A masih memenuhi persyaratan mutu dan keamanan produk sosis berdasarkan SNI 7755:2013 tentang sosis ikan, dimana persyaratan kadar abu untuk sosis ikan maksimal $68 \%$. 
Kadar abu tidak menunjukkan perbedaan yang signifikan antara produk sosis dan daging ikan gulamah. Kadar abu maksimal yang dipersyaratkan adalah 2,5\% (SNI 7725:2013). Produk sosis ikan gulamah masih memenuhi baku mutu yang ditetapkan. Hasil kadar abu ini hampir sama dengan produk sosis ikan komersil yaitu sekitar 1,71 2,61 (Huda et al., 2012). Hasil ini lebih tinggi bila dibandingkan dengan kadar abu sosis ikan lele dumbo sebesar 1,25\% (Anggaraini et al. 2016), namun lebih rendah jika dibandingkan dengan sosis ikan kembung, dan ikan kurisi masing sebesar 2,65\% (Nalendrya et al., 2016; Widodo, 2008). Penambahan garam pada proses pengolahan dapat meningkatkan kandungan kadar abu, hal ini disebabkan garam memiliki kandung mineral seperti Natrium (Venugopal, 2006). Konsentrasi kadar abu juga dapat dipengaruhi oleh penambahan tepung tapioka dan gula. Selain meningkatkan komposisi karbohidrat dalam produk olahan, penambahan tepung dan gula yang mengandung karbohidrat tinggi juga dapat meningkatkan kadar abu. Hal ini dikarenakan karbohidrat merupakan makro molekul yang mengandung atom karbon (Venugopal, 2006).

Hasil analisis proksimat menunjukkan terjadi penurunan kadar protein setelah terjadi pengolahan ikan gulamah menjadi sosis ikan. Namun penambahan daging ayam tidak mempengaruhi kadar protein sosis produk A. Kandungan protein pada sosis ikan tidak memenuhi persyaratan mutu sosis ikan yaitu minimal 9\% (SNI 7725:2013). Hasil ini juga lebih rendah jika dibandingkan dengan kadar protein sosis ikan lele (17,96 \%). Ikan kembung (9,4\%), dan ikan kurisi (14,99\%) (Anggaraini et al., 2016; Nalendrya et al., 2016; Widodo, 2008). Sosis ikan komersial mengandung protein sebesar 8,18-10,77\% (Huda et al., 2012) Protein pada sosis ikan memiliki fungsi untuk mengemulsi lemak dan mengikat air, jika kandungan protein terlalu rendah hal ini akan berpengaruh terhadap kekentalan dari sosis sehingga akan mempengaruhi tekstur sosis. Sosis dengan protein rendah akan cenderung tidak stabil dan mudah rusak pada saat proses pemasakan (Rust, 1987). Kadar protein yang direndah dapat dipengaruhi oleh penggunaan daging ikan yang terlalu sedikit (Huda et al., 2012), namun hal ini dapat diatasi dengan penambahan protein dalam bentuk nisin, karagenan, ataupun isolate kedelai untuk meningkatkan teksur kekentalan dari sosis ikan.

$$
\text { Hasil proksimat menunjukkan }
$$
terdapat peningkatan nilai lemak kasar setelah dilakukan pengolahan ikan gulamah menjadi produk sosis. Kadar lemak pada sosis ikan gulamah belum memenuhi persyaratan 
mutu sosis ikan yaitu maksimal 7\% (SNI 7725:2013). Nilai ini jauh lebih tinggi bila dibandingkan dengan sosis ikan lele, ikan kembung, dan ikan kurisi yaitu sebesar 0,785,48\% (\%) (Anggaraini et al., 016; Nalendrya et al., 2016; Widodo, 2008). Penambahan lemak pada produk olahan sosis ikan bertujuan untuk meningkatkan tekstur sosis serta rasa yang lebih baik. Apabila lemak yang ditambahkan terlalu sedikit akan menyebabkan tekstur adonan berkerut ketika dilakukan proses pemanasan, bila terlalu banyak tekstur sosis akan terlalu lunak (Wilson, 1981). Peningkatan kadar lemak pada produk sosis dapat dipengaruhi oleh penambahan minyak sawit yang pada produk sosis ikan.

\section{KESIMPULAN}

Penambahan daging ayam sebesar 30 \% pada sosis ikan gulamah menghasilkan nilai kesukaan panelis berkisar antara suka sampai agak suka. Karakteristik kenampakan bulat lonjong, homogen, mengkilat, aroma dan rasa spesifik serta tekstur yang lembut dan kenyal, namun belum sesuai dengan SNI 7725:2013.

\section{DAFTAR PUSTAKA}

Afrisanti, D. W. 2010. Kualitas Kimia Dan Organoleptik Nugget Daging Kelinci dengan Penambahan Tepung Tempe.Skripsi. Fakultas
Pertanian Universitas Sebelas Maret, Surakarta.

Anggaraini DR, Tejasari, Praptiningsih YS. 2016. Karakteristik fisik, nilai gizi, dan mutu sensori sosis lele dumbo (Clarias gariepinus) dengan variasi jenis dan konsentrasi bahan pengisi. Jurnal Agroteknologi 10(01):25-35

Carpenter RP. Lyon DH. Hasdell TA. 2000. Guidelines for Sensory Analysis in Food Product Development and Quality Control.2nd Ed. Maryland (US):Marylands Aspen Publisher.

Ellmore, G., dan Feldberg, R. 1994. Allin lyase localization in bundle sheaths of the garlic glove (Allium sativum). J Botany Am 81: 89-94.

Harmain, R. 2011. Aplikasi Bakteri Lactobacillus Plantarum 1 b1 Pada Sosis Fermentasi Ikan Patin (Pangasius sp.). [Tesis]. Bogor: Sekolah Pasca Sarjana Institut Pertanian Bogor.

Huda N, Alistair TLJ, Lim HW, Nopianti R. 2012. Some Quality Characteristics of Malaysian Commercial Fish Sausage. Pakistan Journal of Nutrition 11 (8): 700-705

Hui YH, Kit Nip W, Rogers RW, Young OA. 2001. Meat Science and Applications. New York: Marcel Dekker Inc

Leha M A dan Moniharapon A. 2013. Fortifikasi Surimi Ikan Rucah terhadap Mutu Mie Basah. Majalah Biam 1 (9): 14-22.

Muchbianto, R. 2009. Pengaruh Penambahan Limbah Udang Terfermentasi Aspergillus niger pada Pakan Terhadap Kualitas Fisik Daging Ayam Broiler. Skripsi. 
Program Studi Teknologi Hasil Ternak. Fakultas Peternakan. Universitas Brawijaya. Malang.

Nalendrya W, Ilmi IMB, Arini FA. 2016. Sosis Ikan Kembung (Rastrelliger Kanagurta L.) Sebagai Pangan Sumber Omega 3. Jurnal Aplikasi Teknologi Pangan 5(3):71-75.

Park JW. 2000. Surimi and Surimi Seafood. Marcel Dekker., New York.

Putri, E, F, A. 2009. Sifat Fisik dan Organoleptik Bakso Daging Sapi pada Lama Postmortem yang Berbeda dengan Penambahan Keragenan. Skripsi. Bogor:Departemen Ilmu Produksi danTeknologi Peternakan FakultasPeternakan Institut PertanianBogor.

Http://repository.ipb.ac.id

Rust RE. 1987. Sausage Product. In: The Science of Meat and Meat Product. 3rd Ed. J.F. Price and B.S. Schweigert (Ed.). Food and Nutrition Press, Inc., West Port Conecticut.
Soeparno. 2005, IImu Dan Teknologi Daging. Cetakan keempat. Gadjah Mada University Press. Yogyakarta.

Tan Sen Min., Ng Mui Chung, T. Fujiwara, Hooi Kok Kuang and $\mathrm{H}$. Hasegawa. 1987. Handbook on the Processing offrozen Surimi and Fish Jelly Productsin South East Asia. MFRDSEAFDEC. Singapore.

Venugopal V. 2006. Seafood Processing: Adding value through quick freezing, retortable packaging and cook-chilling. CRC Press. New York, pp: 241.

Widodo SA. 2008. Karakteristik sosis ikan kurisi (Nemipterus nematophorus) dengan penambahan isolat protein kedelai dan karagenan pada penyimpanan suhu chilling dan freezing. Skripsi Teknologi Hasil Perikanan, Institut Pertanian Bogor.

Xu MY, Chen YX, Wu CW. 2010. Analysis of Nutrition in the Muscle of Wild and Cultured Nibea albiflora. Journal of Chejiang Ocean University 2010 (04). 